\title{
Research on Southeast Asia's Maritime Thoroughfare Security in the Construction of the Belt and Road Initiative
}

\author{
Yang Jiahao \\ College of Criminal Justice \\ Zhongnan University of Economics and Law \\ Wuhan, China \\ youngpaper@126.com
}

\begin{abstract}
Southeast Asia is a main area in building the Maritime Silk Route. The aim of this study is to explore the probable security risk when constructing maritime thoroughfare and provides suggestions and countermeasures. This paper discusses the requirements to construct new maritime thoroughfare for national economical development. The traditional and non traditional security risks related to the construction of 21st Century Maritime Silk Route are demonstrated in detail. The results show that for the sake of maintaining the security of the thoroughfare and laying a solid foundation for the construction of the Belt and Road Initiative, we need to keep a good relationship with the U.S., crack down on terrorism existence, achieve a proper resolution of territorial disputes in the South China Sea and to actively build the nontraditional security cooperation mechanism.
\end{abstract}

Keywords-Belt and Road Initiative; Southeast Asia; maritime thoroughfare; terrorism; security

\section{INTRODUCTION}

Thoroughfare is different from the road that has the function of general routh or path. Its vocabulary is a thoroughfare rather than the Road. A thoroughfare is the hub of transportation, the throat of the international strategy, the lifeline of national security interests [1]. Therefore, in view of the construction of One Belt And One Road, exploring the maritime silk thoroughfare security of sea lanes of Southeast Asia in the 21 st century is particularly important.

\section{Realistic Considerations of SOUtheast Asia SEA LANES' SECURITY}

The construction of new maritime silk thoroughfare is the development reqirement of regional integration. Since the end of world war two, the three sub-regional integration tides were formed. The first time was 50-60s of the 20th century, and the European Economic Community was the main symbol. The second was in mid and late 1980s to 90s, Europe's single market and North American free trade area and the AsiaPacific Economic Cooperation (APEC) were the main signs. The third wave occurred at the turn of the century, in this period the regional cooperation was developing deeply. In narrow sense, it broke the traditional cooperation mode that the organization of regional economic integration is closely related in geography or is neighbor. Lots of inter-continental economic cooperation organization, for example APEC (Asia-Pacific Economic Cooperation), appeared subsequently. They were beyond the EU (European Union) as well as other integration mode that only limited to countries and regions with similar developmental level. Even Trans-Pacific Partnership (TPP) countries with large difference of economic development were strengthening cooperation. Large region economic cooperation of interregional countries will become increasingly new economic growth point [2]. Therefore, the construction of new maritime silk route initiative is the inevitable result of the global wave of regional integration.

Shipping in the construction of maritime silk thoroughfare strategy occupies an extremely important position [3]. In 2013, Chinese foreign trade shipping continues to increasing, the total reaches $\$ 2.572023$ trillion, accounting for $62.83 \%$ of the total amount of China's foreign trade. The shipping channel security problems on Chinese trade security and economic security, energy security and national security are very important. Whether the ancient sea silk or the new maritime silk thoroughfare, its most strategic basis depends on the Southeast Asia. Sea channel security problems led to the decline of the ancient sea silk, in the construction of new The new maritime silk route, maintain southeast Asia sea channel security is still the main content of the construction of new maritime silk route, even can decide its successful completion. Although the factors affecting the safety of the channel is much, but in general that can be divided into four categories: first, because of national interest, coastal countries in an attempt to control the freedom of the channel; Second, coastal countries internal unstable; Third, coastal countries and external conflicts; Fourth, the competition between neighbors for maritime overlap region. The four types of factors that can lead to conflict in Southeast Asia also exist. However, the current urgent problem needed to be solved in Southeast Asia sea lanes are two as follows.

One is traditional security issues. In the South China Sea territorial dispute is that Southeast Asia's sea lanes are mainly traditional security issues [4]. Until the 1970s, there are no territorial disputes with neighboring countries other than Vietnam authority. After the 1970s, countries, led by Vietnam, the Philippines, start eating into our country in the South China Sea reefs, severely infringing China's sovereignty and security. 
Especially after the end of the cold war, extraterritorial power gradually stepped in the South China Sea, the regional security situation is more complicated. The South China Sea territorial disputes not only has tendency of the Association of Southeast Asian Nations and there are signs of internationalization. In 2002 the United States declared that it must control the 22 worldwide important international strategic thoroughfares that include Southeast Asia, Strait of Malacca, the Sunda Strait, Makassar Strait, Lombok strait. If the United States blocked the Southeast Asia Sea lanes, the basic control of the islands and a peninsula of Southeast Asia, and the western Pacific and Indian Ocean plays a decisive role in the future, including the control of the Middle East oil strategy route back and forth. India's look east policy, Japan's southward policy and the Asia Pacific rebalancing strategy of the United States is competing in the South China sea, to the already simmering in the South China Sea waves surging tide from time to time, this will seriously threaten the security of the Southeast Asia sea thoroughfare.

Those who have territorial disputes with China in countries such as Vietnam, Philippines, Malaysia and Brunei think that if these reefs occupied not only can obtain abundant Marine resources, such as Malaysia, 70\% of the oil exports from Nansha Waters, but also directly or indirectly controls from the strait of Malacca to Japan, from Singapore to Hong Kong from Guangdong to Manila, even from east Asia to west Asia, Africa and Europe's major sea lanes. Therefore, these countries without considering, on the one hand, seize reefs and build up Arms; On the other hand to take an active part in the United States led the exercises in the South China Sea. The South China Sea territorial disputes have momentous upheaval to trend, southeast Asia sea lanes is like waves. The negative effects on the construction of new The new maritime silk route is quite serious, once the outbreak of military conflict in the south China sea waters, sea lanes are at risk of blocked to cut off the southeast Asia. This is not just about the safety of the China's national interests, to some extent determining the success or failure of the construction of the new maritime silk thoroughfare.

Another kind of threat is non-traditional security issues [5]. After the end of the Cold War, with the loss of the traditional security threat to the international community, in the September 11, 2001 terrorist attacks and the epidemic of SARS in 2003 marked rages on, non-traditional security issues are increasingly becoming new threats of the international community. On the issue of building new maritime silk route, piracy and maritime terrorism is the main threat to Southeast Asia Sea thoroughfare' safety. Piracy has become international public nuisance, for international trade and sea lanes pose a serious security threat. In a world of pirates' five big scary waters, that includes the Strait of Malacca and the entire Southeast Asian Waters. The resulting joint anti-terror, America and Southeast Asia will inevitably impact on thoroughfare construction. After America's war on terror in Afghanistan over a decisive victory, it announces to start the second phase of the war on terror. The United States will use military means to combat terrorism in Southeast Asia as its top priority. The former US President George Bush calls Southeast Asia as the cracking down on a second front in the war on terror. U.S. naval and air forces enter and use the southeast
Asian countries more military bases, American and southeast Asian countries often hold bilateral and multilateral military exercises, and assist the southeast Asian countries in counterterrorism operations, strengthen the dominant position in Asia and the Pacific. The "return to southeast Asia" although help to counter terrorism, but it will make the political situation in Southeast Asia becomes more complex, increasing the likelihood of U.S. military intervention in other Asia-pacific affairs. But at the same time, it is likely to be aroused in southeast Asia with a population of 200 million of the forces of the Islamic religious sentiment and political consciousness, to further promote international terrorism in southeast Asia, the impact of some countries peace of political and economic situation and social stability, it also go against the stability of the region. This in turn will create conditions for the United States of meddling in the regional affairs, and the development of economy and regional cooperation is not implemented in the unstable environment. This is critical to China. Thus China will be in the half moon encirclement that the United States built. The construction of new maritime silk thoroughfare will be in urgent need to solve safety problems of Southeast Asia Sea thoroughfare.

\section{Some Suggestion About Construction And Security OF NeW Maritime SilK ThOROUGHFARE}

Construction new maritime silk thoroughfare is the hope that through economic and trade exchanges to promote common development, but maritime trade in narrow water could have catastrophic consequences, making the sea thoroughfare security becomes one of the first issues of global concern. In Southeast Asia, both traditional and non-traditional security, not only affect the sea lanes safe, but also determining the construction of the new The new maritime silk route. In order to maintain the Southeast Asia Sea lanes safe and smooth construction of new maritime silk thoroughfare, the following questions should be well dealt with.

\section{A. Properly Handle the Relation with the United States}

The United States is neither neighboring country of maritime silk route, also not the claimants to the South China Sea reefs, it is country outside region. In the maintaining of Southeast Asia Sea thoroughfare security issues, we need to properly handle the relations with the United States. This is mainly of the current international system.

There is a consensus: international relations among today's world is unipolar system, the United States is the only superpower. Despite China's rapid rise, the BRICs countries enhanced strength, but the so-called "rule" of China and the United States the poles of the system does not exist, the comprehensive strength of the two countries. In terms of hard power, the United States in 2014 GDP of \$17.149 trillion, ranked first in the world, China's per capita GDP in that year ranked 80th in the world; According to the power ranking 2014 world military powers, the United States remains the world's leading military powers, Russia's second, China's third; In terms of soft power, according to professor Yan Xuetong quantitative study indicating "China's soft power is up and down in the $1 / 3$ of United States". Unipolar system has two important influences on China's diplomatic behavior: first, the 
"checks and balances the will of the American power unipolar weakened China; second, the United States to consolidate its position of trying to make it become" impossible challenge ". In this background, no country in the world like balance theory use effective checks and balances strategy to America's unilateralism, mainly due to "the power of the dominant country too big to be checks and balances". In accordance with the "free rider" theory and the reality of power asymmetry between China and the United States, other countries are willing to follow the United States, rather than checks and balances it, which makes China's lack the Allies to check and balance the United States.

America has two ways to protect the unipolar hegemony, growing your own power or reducing the strength of the opponent, be sure to keep yourself and your opponent's strength gap within the scope of the security, the supremacy of stable or not depends largely on the power distance between hegemony countries and challenges. In the face of the rise of China, the United States in the Asia-pacific rebalancing strategy mainly contain China. However, bilateral trade volume in 2014 was $\$ 590.68$ billion, both sides each other each other's second largest trading partner, the depth of the interests of both countries are interdependent, are difficult to bear the consequences of direct conflict, this makes the United States to contain China and want to stay in touch.

In the South China Sea sovereignty dispute, although the policies of the United States "has obvious tendentiousness, favoritism and provocative", but the United States and Vietnam, the Philippines and other countries of the south China sea policy has essential difference. The aim of the United States is the world hegemony, in the South China Sea or Southeast Asia is given priority to maintain the stability of the region, "the south China sea thoroughfare that was damaged would endanger America's economy", argues that the parties to the dispute in a peaceful solution to the sovereignty disputes under international law. These claims in the United States and China's position are not completely opposite. China actively promotes the implementation of the declaration on the conduct of parties of the South China Sea, to maintain the stability of the South China Sea. Therefore, our country needs to actively deal with the relations with the United States, let they understand, as long as it doesn't harm China's core interests, not by force to suppress our country through its own development and realization of peaceful rise, China is now the international order vindicator rather than a revolutionary. We can jointly maintain Southeast Asia sea thoroughfare security, in order to reduce the construction of new maritime silk route external resistance.

\section{B. Insist on the Autonomy of the Traditional Security for Southeast Asia Maritime Thoroughfare}

China has indisputable sovereignty to the reefs within nine section of South China Sea. This is based on laws and documents. Before the 1970s, China and Vietnam, the Philippines and other countries do not exist in the South China Sea territorial disputing region; the international communities including ASEAN countries have recognized China's sovereignty. In 1968, after investigation that the United Nations economic commission for Asia and the Far East thinks that the South China Sea may contain abundant oil and gas resources and the ensuing oil crisis, deepening the world's thirst for oil resources, such as Vietnam, the Philippines began eyeing the South China Sea territory in China. The signing of the 1982 United Nations convention on the law seems to be found sound for individual southeast Asian countries, the legal basis for the south China sea territory, territorial waters, some countries put into practical action, illegal encroach on our territory in the south China sea, crazy plundering Marine resources.

More seriously is that some Southeast Asian countries with its so-called power balance strategy as an excuse do not hesitate to pull the United States, Japan, India and other countries of South China Sea territorial disputes. Now each year in the United States and Vietnam, the Philippines, Thailand, Singapore, Malaysia and other ASEAN countries hold various exercises in the South China Sea. One of the main purposes is to control the route of the South China Sea, while Vietnam, the Philippines and its type with the help of outside power to force on territorial disputes in China. In the South China Sea territorial dispute involves only China and Vietnam, the Philippines, Malaysia and Brunei six-party the five problems, but because of outside power collusion with Vietnam and other countries, the South China Sea sovereignty dispute had a tendency to internationalization which will be more complicated. In terms of experience to resolve international conflicts, territorial disputes involving the high political (high politics says) field problem is difficult to in a short period of time, the complexity of the south China sea territorial dispute determines the problem existing in the longterm. Shelve dispute, common development is the international common before the settlement of disputes on temporary measures. From the current situation to see, not all dispute parties tend to shelve dispute, common development, not all countries would like to jointly safeguard the stability of the situation in the South China Sea. As a U.S. military personnel have claimed: now the problem that we are most worried about is Vietnam, the United States suddenly armed conflict, the United States and China about this when the United States may be forced to roll. It is certainly that members of the ASEAN state-owned intensified conflict.

Territory is a prime requisite of a country, is the foundation of the state existence and development, "territorial security is the necessary premise of national survival and safety". Safeguard national sovereignty and security must rely on our own defense force, which is decided by an independent foreign policy of China. Our country neither alliance with any country or rely on any power and power group, don't count on others to maintain the sovereignty and security of our country. Therefore, we must safeguard national sovereignty and security by strengthening the state power and the use of political, military, diplomatic and other measures to improve the ability of protection from external threats and challenges. That is to say, solving the problem of political, military and other traditional security must rely on our own strength. Countries such as Vietnam, the Philippines encroach on the South China Sea reefs, serious damage to national security in our country, both also threat the safety of sea lanes southeast Asia. In view of the challenge for the South China Sea territorial sovereignty, China 
should strengthen the power in the region, accelerate the construction of the navy, improve military deterrence and maintain the stability of the South China Sea so as to protect the security of the Southeast Asia Sea lanes.

\section{Establish Cooperation Mechanism of Non-traditional Security Issues on the Southeast Asia Sea Thoroughfare}

Globalization is not just the source of international conflict, is also the source of the international security cooperation [6]. Different from traditional security, non-traditional security "transnational, sociality, diverse and interconnected" determines the non-traditional security issues which are not a national of individual issues, and also the threats of other countries or the common threats of the international community. Piracy and maritime terrorism threats against China and the ASEAN countries, the force of a nation is not China or ASEAN to cope with challenges. As a result, dealing with non-traditional security issues of national security and the whole international society becomes more and more closely related to peace, security, in view of this, cooperative security becomes the effective ways to maintain international security. For example, in order to lift the central Asia and the threat of terrorism in northwest China, sponsored by the Shanghai cooperation organization in our country, the security cooperation with the neighbouring countries and has obtained the good effect.

Southeast Asia Sea thoroughfare is the key to the construction of new maritime silk route. China's economic and social sustainable development increasingly relies on the world, to make our country more need to strengthen security cooperation with Southeast Asia, in order to maintain the safety of sea route. However, the security cooperation between China and ASEAN isn't enough, and that is difficult to address common security challenges. Our country is the high contracting party about the United Nations Convention on the Law of the Sea, the Illicit Behavior Endangering Maritime Navigation Safety Convention, the Anti-piracy and Armed Hijackers in Asia Cooperation Agreement of the Contracting States. In 2002, China and ASEAN signed the joint declaration about the field of non-traditional security cooperation, to crack down on piracy and maritime terrorism is the main content of security cooperation. Whether it is a convention or declaration, within the category of international law belongs to the nature of soft law, on international relations actors are not rigid constraint function, and there were significant differences in the structure and function of the Shanghai Cooperation Organization (SCO).

In view of the situation, our country needs to strengthen the efforts in the following aspects: first, we should be actively advocated and ASEAN countries to build as the Shanghai cooperation organization similar to non-traditional security cooperation mechanism, strengthen the construction of rigid security mechanism, and jointly combat a security threat to the region stability; Second, to expand the function of the existing cooperation mechanisms. Mainly to expand " $10+1$ " and " $10+3$ " the function of the cooperation mechanism, mainly from the organization for economic cooperation and gradually expand to security cooperation. Due to the southeast Asia sea thoroughfare security closely with the interests of northeast Asia countries such as South Korea, Japan, expanding the "10 +1 " and " $10+3$ " security mechanism construction which should both comply with the security interests of northeast Asia countries and also limit the ownership of this region. Once again, we should strengthen the construction of bilateral security cooperation mechanism. The advantage of bilateral security cooperation is embodied in a purpose and flexibility and convenience. Such as, in 2005 years, the two countries signed the navy north gulf joint patrols agreement in order to maintain the stability of the north gulf. In the face of increasing non-traditional security threats, we need to strengthen bilateral security cooperation with the Philippines, Malaysia and other countries, jointly maintaining Southeast Asia Sea thoroughfare security, and reducing the resistance of the construction of new maritime silk route.

\section{SUMMARY}

After analyzing and demonstrating in detail, this paper gets the conclusions as follows.

The security risks in the process of constructing the maritime thoroughfare are: the further actions of the US AsiaPacific Re-balance; Southeast Asia countries' worries and counters; interference of hot-spot security issues along the line; non-traditional security threats along the line. The probable measures of creatively processing the security problems above are: bring the US and its allies to the construction of the Route and make full preparations to counter it; rationally managing the contradictions and divergences with relative countries; creatively solving the peripheral hot-spot security issues; cooperating to face the non-traditional security threats.

\section{ACKNOWLEDGMENT}

This work was financially supported by Military science project of the National Social Science Fund of China (16GJ003-163).

\section{REFERENCES}

[1] Liu Yuejin, National Security Studies (in Chinese). Beijing: China University of Political Science and Law Press, 2004.

[2] Yang Jiechi, rand Integration: Trends of Asian Economic Cooperation (in Chinese). Tianjin: Tianjin Peoples Publishing House, 2007.

[3] Wei Gekun Business College in Guangxi University, Nanning, Chi. Ponderation Over the Rapid Growing Tendency of the Degree of Dependence Upon China's Foreign Trade[J]. Journal of Guangxi University Wuzhou Branch, 2005.

[4] Joshua H. Ho. The Security of Sea Lanes in Southeast Asia[J]. Asian Survey, 2009, 46(4):558-574.

[5] Hegemony System and International Conflicts: American Supportive Behavior in International Armed Conflict (1945-1988) (in Chinese). Shanghai: Shanghai People's Press, 1999.

[6] Levy J S. The causes of war and the conditions of peace[J]. Annual Review of Political Science, 1998, 1(1):139-65. 